\title{
Biochemical and Morphological Characteristics of Acid-Resistant Regenerants of Sugar Beet (Beta
}

\section{vulgaris L.)}

\author{
Olga Zemlianukhina ${ }^{2}$, Natalia Cherkasova ${ }^{1}$, Tatiana Zhuzhzhalova ${ }^{1}$ and Vladislav Kalaev ${ }^{2}$ \\ 1. Federal State-Funded Scientific Institution “A.L. Mazlumov All-Russia Research and Development Institute of Sugar Beet” \\ (VNIISS), Voronezh Region, Ramonsky District 396030, Russia
}

2. Federal State-Funded Educational Institution of Higher Education "Voronezh State University” (VSU), Universitetskaya Ploschad 1, Voronezh 394006, Russia

\begin{abstract}
The aim of the paper was to study the metabolite profile and morphological characteristics of sugar beet regenerants exposed to aluminium ions $\left(\mathrm{Al}^{3+}\right)$. The regenerants were selected basing on selective media with sublethal acidity ( $\left.\mathrm{pH} 3.5\right)$. The thrice-repeated passaging of sugar beet microclones of two genotypes in low $\mathrm{pH}$ medium causes certain alterations in the cellular metabolism. The paper demonstrated that peroxidase (POD) and isocitrate lyase (ICL) activity increased in both varieties. At the same time, NADH-dehydrogenase (NADH-DH) activity decreased in hybrid plants. Glucose-6-phosphate-dehydrogenase (gl-6-ph-dh) activity increased in mail sterile (MS) hybrid plants, but reduced in Ramonskaya fertile (RF) hybrid plants. Adaptation to reduced $\mathrm{pH}$ was accompanied by alterations in the isozyme spectra of POD, 1- and 2-esterase, cytochrome c oxidase and malic enzyme (ME). The adaptation process of sugar beet regenerants was also accompanied by an increase in protein synthesis. The level of metabolic response to stress very much depended on the initial genotype of the hybrid. In this experiment, aluminium resistant plants were growing rapidly in selective media. They developed leaves with healthy petioles and blades and had strong root systems.
\end{abstract}

Key words: Beta vulgaris L., sugar beet, induced acid resistance, enzyme activity, isozymes.

\section{Abbreviations}

$\begin{array}{ll}\text { AR } & \text { Acid-resistant } \\ \text { RF } & \text { Ramonskaya fertile } \\ \text { MS } & \text { Mail sterile } \\ \text { POD } & \text { Peroxidase } \\ \text { ICL } & \text { Isocitrate lyase } \\ \text { IDH } & \text { Isocitrate dehydrogenase } \\ \text { MDH } & \text { Malate dehydrogenase } \\ \text { ME } & \text { Malic enzyme }\end{array}$

\section{Introduction}

Sugar beet needs a peculiar soil and a unique climate for its successful cultivation. For good yields, highly fertile soil is required with a neutral soil solution reaction and a high concentration of mineral

Corresponding author: Olga Zemlianukhina, Ph.D., research fields: plant biotechnology, microbiology and biochemistry. elements. Long-term use of fertilizers alters physical and chemical characteristics of soils dramatically, which is true even for highly resistant chernozem soils. This, in turn, often results in increased soil acidity and damages the plants $[1,2]$. There are about 50 million hectares of acid soils in Russia. This is $32.8 \%$ of all the agricultural lands in the country [3]. One of the major constituents of acid soils is aluminium [4].

Aluminium is one of the three most abundant elements in the Earth's crust. Its solubility in neutral soils is very low, so it is not toxic for plants. However, an increase in soil acidity results in the higher solubility of aluminium ions $\left(\mathrm{Al}^{3+}\right)$ and thus causes the inhibition of root development [5]. When soil $\mathrm{pH}$ falls lower than 5.0, plants have less access to phosphorus, sulphur, calcium, potassium, magnesium and molybdenum [6]. 
Biochemical adaptation strategies of plants may vary depending on the biochemical mechanism employed. There are three types of biochemical mechanisms of plants adaptation: to change the class of macromolecules, to change the number (the concentration) of macromolecules, or to adjust the functions of macromolecules [7]. Among the most common adaptive macromolecules are enzymes engaged in cellular metabolism. It is considered that exposure to stress affects both genetic and epigenetic parameters. Changes in the latter result in fine-scale variations of the genome compensating for the negative effects of stress [8].

The most common response to stress is activation of the antioxidant system, and most biochemical studies have been focusing on this system. Thus, in the study by Artemieva et al. [9], the way that saline conditions affect the activity of fumarate hydratase and aconitase was studied. These enzymes function in the catabolic and anabolic processes of the tricarboxylic acid cycle of $\mathrm{C}_{3}$ - and $\mathrm{C}_{4}$-plants, and the study demonstrated their independent regulation. Epryntsev and Fedorina [10] found that in saline conditions, enzymes of the MDH complex play a great role. During the first stages of corn seed germination in saline conditions, these enzymes became active and caused the accumulation of pyruvate (in leaf sheath) and malate (in leaf sheath and mesophyll). However, the number of intermediates decreased gradually. The authors pointed out that the tricarboxylic acid cycle and the Hatch-Slack pathway (a light-independent photosynthetic process in $\mathrm{C}_{4}$-plants) were induced by $\mathrm{NaCl}$ [10]. Sugar beet plants have not yet been studied from this point of view.

In vitro selection is a very powerful and environmentally friendly method for obtaining new plant varieties, as the greater sensitivity of isolated tissues to various types of stress allows for significant increase in the level of plant genetic variation [11, 12].

By modelling the effects of abiotic factors (selecting agents) on plants' organs and tissues in vitro, it can be obtained that plants were highly resistant to acid medium [13-16]. Of great importance are morphobiological, biochemical and other characteristics, which allow for effective selection. Mechanisms of plants adaptation to stress factors of various origin presuppose similar changes in genes expression. These changes lead to an increase or decrease in the activity of several enzymes regulating the cell cycle; an increase or decrease in the amount of organic acids secreted; as well as an increase or decrease of total protein, and alterations in the isozyme spectrum [13].

Therefore, it seems vital to study the adaptive potential of AR regenerants of sugar beet from the point of view of biochemistry. The aim of this research was to study the metabolite profile and morphological characteristics of sugar beet regenerants exposed to aluminum ions.

\section{Materials and Methods}

The certain components of the sugar beet hybrid used in this experiment were selected in Ramon. In particular, cytoplasmic male sterile hybrid 2093MS, heterotic fertile hybrid 2093RF, and acid resistant AR 2093MS and AR 2093RF hybrids of sugar beet were obtained in vitro.

In order to model the acidity of the nutrient medium in vitro, $0.02 \%$ and $0.05 \% \mathrm{AlCl}_{3}$ were used, resulting in $\mathrm{pH}$ values of 3.8 and 3.5 , respectively. Acid resistant regenerants were selected as a result of thrice-repeated passaging ( $\mathrm{pH}$ control value 5.8): first passage: seed germination ( $\mathrm{pH} 3.5$ ); second passage: selection of plantlets ( $\mathrm{pH} 3.5$ ); third passage: selection at the root formation stage ( $\mathrm{pH} 3.8$ ).

The resistance level was accessed in the 3 rd passage using the root length index (RLI), i.e., the ratio of the root length in the experimental group to the mean root length in the control group [17].

Plants were cultivated at $23-26{ }^{\circ} \mathrm{C}$, with illumination of 5,000 lux, a 16-h photoperiod and 70\% relative humidity [18]. Prior to biochemical tests, 
regenerants of both the experimental and control groups were cultivated on a control medium at $\mathrm{pH} 5.8$ for one year.

In order to obtain enzyme preparations, sugar beet plants were ground with glass sand in $0.1 \mathrm{M}$ Tris- $\mathrm{HCl}$ buffer at $\mathrm{pH} 7.5$, and centrifuged for $7 \mathrm{~min}$ at $\times 20,000$ g, $4{ }^{\circ} \mathrm{C}$, in a CM50 ELMI centrifuge (Latvia). The supernatant was stored in BIOSAN CH-100 dry block (Latvia) at $-3{ }^{\circ} \mathrm{C}$. The following enzymes were tested: glucose-6-phosphate-dehydrogenase (gl-6-ph-dh; EC1.1.1.49), POD (EC1.11.17), ICL (EC4.1.3.1), IDH (EC1.1.1.42), malate dehydrogenase (NADH-MDH; EC1.1.1.37), malic enzyme (NAD-ME; EC1.1.1.39) and NADH-dehydrogenase (NADH-DH; 1.6.99.1) [19]. The enzyme activity was calculated using the extinction coefficients and the unit of activity was determined as the amount of enzyme producing 1 $\mu \mathrm{mol}$ of substrate in $1 \mathrm{~min}$ at $25{ }^{\circ} \mathrm{C}$. All the measurements were performed by means of UNICO 2800 spectrophotometer (USA).

Analysis of the isozyme spectrum was performed in vertical blocks of $7.5 \%$ polyacrylamide gel in accordance with the standard Davis's method. Electrophoresis was performed in order to reveal isoforms of POD, 1- and 2-esterase, cytochrome c oxidase, NADH-DH, MDH and IDH [20, 21].

The soluble protein content was measured using the Bradford method, with bovine serum albumin (Sigma) as a standard.

The paper presents the average results of five biological repeats of the experiments performed. The results were processed statistically using the "Stadia" software package. The procedures of data grouping and processing were described by Kulaichev [22]. A comparison of the reliability of the difference in the total activity $(\mu \mathrm{mol} / \mathrm{min})$ and specific activity $(\mu \mathrm{mol} / \mathrm{min} / \mathrm{mg}$ ) between the control and experimental samples of the two genotypes was performed by means of the Van der Varden rank $X$-test.

\section{Results and Discussion}

Plants are highly susceptible to stress, as they are dependent on their habitat and growing conditions. But this is also the thing that makes them a very good research object, as they allow to study the effects of adverse environmental factors. Understanding the processes of plants' resistance to external suboptimal factors helps to regulate their growth and development.

Since the early 1960s (1980s in Russia), three components have been used to obtain high productive hybrids of monogerm sugar beet: (1) female plants with cytoplasmic male sterility (CMS) (MS-hybrid); (2) heterotic fertile pollinator (HP); (3) male sterility maintainer (O-type). In this experiment, plants were obtained by microclonal propagation of two components (genotypes) of sugar beet hybrids (lines): (1) genotype with CMS (MS-hybrid) and (2) heterotic fertile pollinator of the hybrid cultivated by the researchers of A.L. Mazlumov All-Russia Research and Development Institute of Sugar Beet. During the cultivation stage of mature embryos of sugar beet, it was found that in selective media with sublethal acidity $(\mathrm{pH} 3.5)$, the survival rate of the plantlets was about $50 \%$. The selection of stable microclones was based on the root length index after further four-week cultivation of the regenerants in root medium ( $\mathrm{pH}$ 3.8) (Fig. 1). The selected microclones had well-developed root systems. For $58.5 \%-67.0 \%$ of regenerants, the root length was $3.3-5.7 \mathrm{~cm}$. The root growth rate for stable regenerants varied from 1.0 to 1.1 depending on their genotype (Table 1). Morphological analysis of the microclones demonstrated that they grew rapidly in selective media. They developed leaves with healthy petioles and blades that had oblique apices and V-shaped bases. The leaves were corrugated and reached their maximal width in the middle. The blades were green. The growth rate of the plants varied from $1.0 \mathrm{~cm}$ to $2.74 \mathrm{~cm}$, which was $42.9 \%-57.2 \%$ of the initial height. Thus, AR hybrids of sugar beet were obtained. 


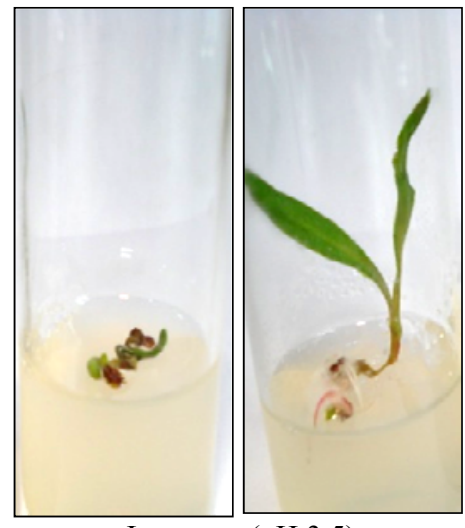

I passage (pH 3.5)

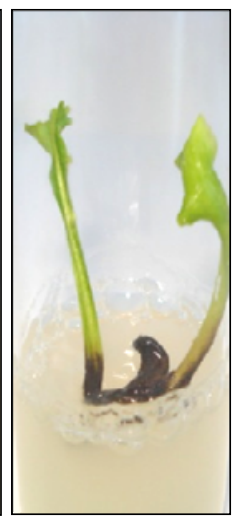

II passage ( $\mathrm{pH} 3.5)$

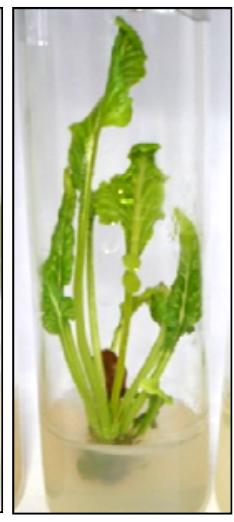

Fig. 1 Selection stages of acid resistant regenerants in selective media.

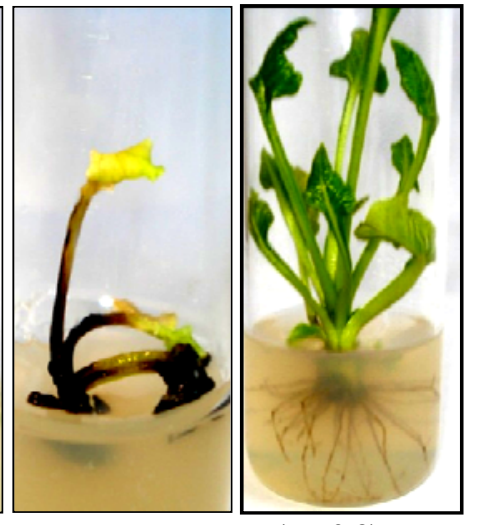

III passage (pH 3.8)

I passage: primary selection in the seed germination stage (left—dead plantlet; right—healthy growth); II passage: secondary selection of regenerants (left—dead regenerant; right—healthy growth); III passage: tertiary selection of microclones in the root formation stage (left—dead control regenerant; right—AR plant with roots).

Table 1 Effect of the medium's acidity on the root system development and the growth of control and stable microclones of sugar beet.

\begin{tabular}{llll}
\hline Genotype & Plant growth rate $(\%)$ & Root length $(\mathrm{cm})$ & Root length index \\
\hline $\begin{array}{l}\text { 2093MS } \\
\text { (pH 5.8, control group) }\end{array}$ & $60.1 \pm 4.10$ & $5.6 \pm 0.85$ & $1.0 \pm 0.04$ \\
$\begin{array}{l}\text { AR 2093MS } \\
\text { (pH 3.8, experimental group) }\end{array}$ & $57.2 \pm 5.00$ & $5.7 \pm 1.65$ & \\
\hline $\begin{array}{l}\text { 2093RF } \\
\text { (pH 5.8, control group) }\end{array}$ & $52.3 \pm 5.10$ & $3.0 \pm 0.50$ & $1.1 \pm 0.06$ \\
$\begin{array}{l}\text { AR 2093RF } \\
(\mathrm{pH} 3.8, \text { experimental group) }\end{array}$ & $42.9 \pm 6.40$ & $3.3 \pm 0.85$ & \\
\hline
\end{tabular}

It is very difficult to determine the primary target of any adverse factor. It is known, however, that practically any stress (higher temperature, draught, saline conditions, etc.) leads to an increase in reactive oxygen intermediates [23]. POD is a stress stimulated enzyme; the more reactive oxygen intermediates there are in the cells, the more active the enzyme becomes, as its function is to break down hydrogen peroxide and terminate free-radical processes. Acid resistant plants (both MS and RF hybrids) demonstrated reliable increase in POD activity by 2.4-3.4 times as compared to the control group. As the initial specific activity, level in RF plants was three times higher than that in MS plants, it can be concluded that lower $\mathrm{pH}$ is likely to affect MS genotype more. Oxidative stress causes alterations in the isozyme spectrum with new activity zones appearing (MS, RF) and some of the activity zones (MS) becoming absent. Alteration in the enzyme's activity and the number of its molecular forms is one of the mechanisms that allow plants to resist stress caused by lower $\mathrm{pH}$.

In this experiment, sugar beet regenerants adapted to lower $\mathrm{pH}$ (3.5) medium was transplanted to the control medium. Even after a one-year cultivation period in such conditions, the specific activity of POD was three times higher in the AR 2093MS experimental samples than in the control 2093MS samples $(P<0.01)$. In the 2093RF hybrids, the activity increased by 1.2 times. The initial enzymic activity in the control RF group was reliably measured $(P<0.01)$, and was three times higher than in the MS group (Table 2). The isozyme spectra of POD in the control and experimental samples were also different (Table 3).

Due to several factors, by regulating the dissociation of oxidation and phosphorylation, mitochondria play a great role in plant response to 
Table 2 Total and specific activity of enzymes in the control and experimental AR hybrids of sugar beet.

\begin{tabular}{|c|c|c|c|c|c|c|c|c|c|c|c|c|c|c|}
\hline \multirow[b]{2}{*}{ Sample } & \multicolumn{2}{|c|}{ POD } & \multicolumn{2}{|c|}{$\begin{array}{c}\text { NADH } \\
\text {-DH }\end{array}$} & \multicolumn{2}{|c|}{ gl-6-ph-dh } & \multicolumn{2}{|c|}{ ICL } & \multicolumn{2}{|c|}{ IDH } & \multicolumn{2}{|c|}{$\mathrm{MDH}$} & \multicolumn{2}{|c|}{$\mathrm{ME}$} \\
\hline & $\begin{array}{l}\text { Total } \\
\text { activiy } \\
(\mu \mathrm{mol} / \mathrm{min})\end{array}$ & $\begin{array}{l}\text { Specific } \\
\text { activity } \\
(\mu \mathrm{mol} / \mathrm{min} \\
/ \mathrm{mg})\end{array}$ & $\begin{array}{l}\text { Total } \\
\text { activiy } \\
(\mu \mathrm{mol} / \\
\mathrm{min})\end{array}$ & $\begin{array}{l}\text { Specific } \\
\text { activity } \\
(\mu \mathrm{mol} \\
/ \mathrm{min} / \mathrm{mg})\end{array}$ & $\begin{array}{l}\text { Total } \\
\text { activiy } \\
(\mu \mathrm{mol} / \\
\mathrm{min}) \\
\end{array}$ & $\begin{array}{l}\text { Specific } \\
\text { activity } \\
(\mu \mathrm{mol} / \\
\mathrm{min} / \mathrm{mg})\end{array}$ & $\begin{array}{l}\text { Total } \\
\text { activiy } \\
(\mu \mathrm{mol} / \\
\mathrm{min})\end{array}$ & $\begin{array}{l}\text { Specific } \\
\text { activity } \\
(\mu \mathrm{mol} / \\
\mathrm{min} / \mathrm{mg})\end{array}$ & $\begin{array}{l}\text { Total } \\
\text { activiy } \\
(\mu \mathrm{mol} / \\
\mathrm{min})\end{array}$ & $\begin{array}{l}\text { Specific } \\
\text { activity } \\
(\mu \mathrm{mol} / \\
\mathrm{min} / \mathrm{mg})\end{array}$ & $\begin{array}{l}\text { Total } \\
\text { activiy } \\
(\mu \mathrm{mol} / \\
\mathrm{min}) \\
\end{array}$ & $\begin{array}{l}\text { Specific } \\
\text { activity } \\
(\mu \mathrm{mol} / \\
\mathrm{min} / \mathrm{mg})\end{array}$ & $\begin{array}{l}\text { Total } \\
\text { activiy } \\
(\mu \mathrm{mol} / \\
\mathrm{min}) \\
\end{array}$ & $\begin{array}{l}\text { Specific } \\
\text { activity } \\
(\mu \mathrm{mol} / \\
\mathrm{min} / \mathrm{mg})\end{array}$ \\
\hline MS control & $\begin{array}{l}2.36 \pm \\
0.32\end{array}$ & $\begin{array}{l}3.83 \pm \\
0.68\end{array}$ & $\begin{array}{l}7.68 \pm \\
0.40\end{array}$ & $\begin{array}{l}11.25 \pm \\
0.92\end{array}$ & $\begin{array}{l}22.66 \pm \\
2.70\end{array}$ & $\begin{array}{l}35.43 \pm \\
3.0 \times 4\end{array}$ & $\begin{array}{l}2.916 \pm \\
0.74\end{array}$ & $\begin{array}{l}5.86 \pm \\
1.53\end{array}$ & $\begin{array}{l}30.82 \pm \\
1.22\end{array}$ & $\begin{array}{l}68.03 \pm \\
8.86\end{array}$ & $\begin{array}{l}25.34 \pm \\
1.59\end{array}$ & $\begin{array}{l}36.56 \pm \\
2.14\end{array}$ & $\begin{array}{l}12.96 \pm \\
0.30\end{array}$ & $\begin{array}{l}18.7 \pm \\
0.27\end{array}$ \\
\hline RF control & $\begin{array}{l}3.48 \pm \\
0.35^{\mathrm{a}}\end{array}$ & $\begin{array}{l}11.55 \pm \\
2.40\end{array}$ & $\begin{array}{l}7.87 \pm \\
0.58\end{array}$ & $\begin{array}{l}14.58 \pm \\
1.75^{\mathrm{a}}\end{array}$ & $\begin{array}{l}23.62 \pm \\
0.76\end{array}$ & $\begin{array}{l}75.37 \pm \\
11.09\end{array}$ & $\begin{array}{l}3.888 \pm \\
0.50\end{array}$ & $\begin{array}{l}11.63 \pm \\
2.33^{\mathrm{c}}\end{array}$ & $\begin{array}{l}33.12 \pm \\
29.76\end{array}$ & $\begin{array}{l}87.37 \pm \\
7.81^{\mathrm{a}}\end{array}$ & $\begin{array}{l}29.95 \pm \\
0.53^{\mathrm{a}}\end{array}$ & $\begin{array}{l}55.74 \pm \\
6.03^{\mathrm{b}}\end{array}$ & $\begin{array}{l}9.98 \pm \\
0.55^{\mathrm{b}}\end{array}$ & $\begin{array}{l}18.14 \pm \\
0.86\end{array}$ \\
\hline $\begin{array}{l}\text { MS } \\
\text { experimental }\end{array}$ & $\begin{array}{l}7.92 \pm \\
0.71^{* *}\end{array}$ & $\begin{array}{l}11.57 \pm \\
1.13^{* *}\end{array}$ & $\begin{array}{l}7.58 \pm \\
0.66\end{array}$ & $\begin{array}{l}9.51 \pm \\
0.72^{*}\end{array}$ & $\begin{array}{l}28.61 \pm \\
2.46^{*}\end{array}$ & $\begin{array}{l}41.65 \pm \\
3.61^{*}\end{array}$ & $\begin{array}{l}5.40 \pm \\
0.33^{* *}\end{array}$ & $\begin{array}{l}9.95 \pm \\
0.35^{*}\end{array}$ & $\begin{array}{l}37.63 \pm \\
0.47^{* *}\end{array}$ & $\begin{array}{l}69.91 \pm \\
2.70\end{array}$ & $\begin{array}{l}25.06 \pm \\
1.37\end{array}$ & $\begin{array}{l}31.99 \pm \\
3.25\end{array}$ & $\begin{array}{l}14.5 \pm \\
0.46^{*}\end{array}$ & $\begin{array}{l}18.28 \pm \\
0.82\end{array}$ \\
\hline $\begin{array}{l}\mathrm{RF} \\
\text { experimental }\end{array}$ & $\begin{array}{l}8.03 \pm \\
0.77^{* *}\end{array}$ & $\begin{array}{l}13.61 \pm \\
1.40\end{array}$ & $\begin{array}{l}6.24 \pm \\
0.84\end{array}$ & $\begin{array}{l}8.86 \pm \\
1.01^{* *}\end{array}$ & $\begin{array}{l}24.1 \pm \\
2.82\end{array}$ & $\begin{array}{l}41.04 \pm \\
4.80^{*}\end{array}$ & $\begin{array}{l}6.55 \pm \\
1.88\end{array}$ & $\begin{array}{l}17.09 \pm \\
4.63 \mathrm{c}\end{array}$ & $\begin{array}{l}31.01 \pm \\
0.86\end{array}$ & $\begin{array}{l}82.64 \pm \\
7.94\end{array}$ & $\begin{array}{l}28.42 \pm \\
0.55^{*_{\mathrm{c}}}\end{array}$ & $\begin{array}{l}41.54 \pm \\
3.29^{* \mathrm{c}}\end{array}$ & $\begin{array}{l}12.96 \pm \\
0.33^{* d}\end{array}$ & $\begin{array}{l}18.92 \pm \\
1.35\end{array}$ \\
\hline
\end{tabular}

* Differences with the control are reliable $(P<0.05)$; ${ }^{* *}$ differences with the control are reliable $(P<0.01) ;{ }^{\text {a }}$ differences in the control group for MS hybrid are reliable $(P<0.05)$; ${ }^{\mathrm{b}}$ differences in the control group for MS hybrid are reliable $(P<0.01)$; ${ }^{\mathrm{c}}$ differences in the control and experimental groups for MS hybrid are reliable $(P<0.05)$; ${ }^{\mathrm{d}}$ differences in the experimental group for MS hybrid are reliable $(P<0.05)$. 
Table 3 Isozyme spectra of POD and esterase in the control and AR sugar beet plants in vitro.

\begin{tabular}{|c|c|c|c|c|c|c|c|c|}
\hline \multirow{2}{*}{$\begin{array}{l}\text { Relative } \mathrm{RF} \\
\text { values }\left(R_{f}\right)\end{array}$} & \multicolumn{4}{|c|}{ POD } & \multicolumn{4}{|c|}{ Esterase } \\
\hline & 2093MS & 2093RF & AR $2093 \mathrm{MS}$ & AR 2093RF & 2093MS & 2093RF & AR $2093 \mathrm{MS}$ & AR 2093RF \\
\hline 0.098 & - & - & - & - & + & - & + & - \\
\hline 0.116 & - & - & - & - & - & + & - & + \\
\hline 0.125 & - & + & - & + & - & - & - & - \\
\hline 0.207 , traces & - & - & - & - & + & - & + & - \\
\hline 0.243 & + & + & + & + & - & - & - & - \\
\hline 0.288 & - & - & + & + & & & & \\
\hline 0.561 & - & - & - & - & - & - & + & - \\
\hline 0.593 & + & - & - & + & - & - & - & - \\
\hline 0.658 & - & - & - & - & + & + & + & + \\
\hline 0.663 & + & + & + & + & - & - & - & - \\
\hline 0.677 & + & + & + & + & - & - & - & - \\
\hline 0.681 & + & + & + & + & - & - & - & - \\
\hline 0.707 & - & - & - & - & + & + & + & + \\
\hline 0.725 & + & + & + & + & - & - & - & - \\
\hline
\end{tabular}

+: Enzyme activity zone observed; -: absence of any activity zones.

Table 4 Change in the total protein content per $1 \mathrm{~g}$ observed during the adaptation of sugar beet regenerants to the increased number of $\mathrm{Al}^{3+}$ in the nutrient medium.

\begin{tabular}{ll}
\hline Samples & $\begin{array}{l}\text { Total protein content }(\mathrm{mg} / \mathrm{mL} \text { of } \\
\text { enzyme preparation) }\end{array}$ \\
\hline MS, control & $2.93 \pm 0.17$ \\
RF, control & $2.09 \pm 0.18$ \\
MS, experiment & $3.41 \pm 0.16^{*}$ \\
RF, experiment & $2.88 \pm 0.23^{* *}$ \\
\hline
\end{tabular}

* Differences with the MS-control $(P<0.05)$; ** differences with the RF-control $(P<0.01)$.

stress. A set of mechanisms (called free oxidation) maintain a low level of intracellular oxygen concentration, which helps to prevent mitochondria from forming reactive oxygen intermediates under various types of stress. One such mechanism is the activity of NADH-DH $\left(\mathrm{Ca}^{2+}\right.$-dependent $)$. It is considered to be two NADH-DH enzymes on the mitochondria outer membranes that react differently to various inhibitors [24, 25]. In this research, the total activity of the two enzymes was observed. It showed that the enzyme activity reliably decreases by 1.2 times in AR 2093MS and by 1.6 times in AR 2093RF plants as compared to the control group. As NADH oxidation process releases the assimilated $\mathrm{CO}_{2}$, this may be caused by genetic regulation of the enzyme activity by means of DNA methylation [8].
An increase in protein content observed in acid resistant plants may be accounted for the inhibition of $\mathrm{NADH}-\mathrm{DH}$ activity, which was exactly the case in this experiment. A slight increase in protein content was observed by 1.2-1.7 times in acid resistant RF plants $(P<0.01)$, and by $1.1-1.3$ times in MS plants $(P<0.05)$ (Table 4).

While POD activity increases due to induced alterations, the activity of mitochondrial NADH-DH $\left(\mathrm{Ca}^{2+}\right.$-dependent), on the contrary, reduces, which can be accounted for the fact that the two enzymes are the opposites $[26,27]$. The isozyme spectrum of NADH-DH in all the plants was represented by a single activity zone that started from $R_{f}=0.366$.

The reaction catalyzed by gl-6-ph-dh is the key reaction of the first oxidative phase of the pentose-phosphate cycle. $\mathrm{NADP}^{+}$molecule is reduced to NADPH. The enzyme is allosteric, i.e., when the $\mathrm{NADPH}^{+}$level falls, the enzyme's activity decreases and gl-6-ph is utilized in the glycolysis [7, 28]. It has been demonstrated that under water deficiency and saline conditions, the enzyme activity in experimental plants increased by 1.5 times, parallel to the decrease of $\mathrm{K}_{\mathrm{M}}$ (Michaelis constant) from 0.15 to $0.12 \mathrm{mM}$ in all the components of the 
sugar beet hybrid [29]. In this paper, it was demonstrated that building up resistance is accompanied by a slight increase (by about 1.2 times) in the enzymic activity in MS plants, significant difference with the control $(P<0.05)$. In RF plants, on the contrary, specific activity decreases by 1.8 times, also significant difference with the control $(P$ $<0.05)$. This should mean that adaptive responses to stress in the two genotypes (MS and RF) are different, as the initial specific activity of the enzyme was the same for both types. It was demonstrated that an increase in the gl-6-ph-dh activity along with NADPH-oxidase activity is a protective measure to protect plants from damaging stress [30]. It was also found that oxidative stress is an evolutionary immune response to adverse environment [31].

Sugar beet accumulates oxaloacetate very quickly. ICL is the key enzyme that takes part in the synthesis of serine, glycine and oxaloacetate in higher plants [32, 33]. Previously, it has been demonstrated that under water deficiency conditions caused by adding sorbitol to the nutrient medium, the enzyme activity increased almost twice, and the $K_{M}$ increased by over eight times [34]. Medium oxidation is likely to have the same effect on the activity of ICL (the specific activity increases by 1.7 times in AR MS plants and by 1.5 times in RF plants).

Previous research demonstrated that, apart from the glyoxylate cycle during seed germination, ICL activity is also observed during some other cultivation stages. As plants grow, the cytosolic form of ICL becomes activated. Its activity maximum is observed at a lower optimum $\mathrm{pH}$ (6.5) and depends on the presence of $\mathrm{Mn}^{2+}$ ions [35]. In vitro conditions enhance ontogenetic growth, which accounts for the greater activity of the enzyme. Specific activity of ICL reliably increased by 1.7 times in MS plants, and by 1.5 times in RF plants, significant differences with the control $(P<0.05)$. ICL activity in the RF control group was almost two times higher than that in the MS group $(P<0.05)$.

As to the other enzyme that functions in the same substrate, namely, IDH, its functioning did not see any significant changes. Thus, in the experimental, MS group the activity of ICL was higher by 1.2 times as compared to the control group $(P<0.01)$, while in the $\mathrm{RF}$ group, the activity level remained unchanged. In RF plants, the activity of the enzyme was higher by 1.2 times than in MS plants $(P<0.05)$.

Under the toxic action of aluminium ions, plant roots produce organic acids, such as citrate, oxaloacetate, malate, etc.. Thus, within 15-30 min of exposure to aluminium stress, sugar beet starts secreting malate and oxalate. Within the next $10 \mathrm{~h}$, the secretion level gradually decreased. Organic acids are supposed to chelate aluminium ions, which enhances detoxication process $[11,13,36]$.

Measurements of the activity level of two out of four enzymes of the MDH complex (NADH-dependent MDH and NAD-dependent ME) demonstrated that they have different effects. Thus, in AR 2093RF, the activity of $\mathrm{MDH}$ decreased reliably as compared to the control $(P<0.05)$, while in MS plants, the activity levels in the control and experimental groups were practically the same. MDH activity value in RF plants was higher than in MS plants both in the control and experimental groups by 1.5 times $(P<0.01)$ and 1.3 times $(P<$ $0.05)$, respectively. Specific activity of $\mathrm{ME}$ remained at the same level both in the control and experimental groups of MS and RF plants. Electrophoregrams of ME activity in the experimental MS group demonstrated that the activity zone started from $R_{f}=0.097$ and ended at $R_{f}$ $=0.673$. Adaptation of RF plants does not lead to alterations in the isozyme spectrum of ME.

Esterase is a lysosomal enzyme of the cell cytoplasm. Analysis of the isozyme spectrum of 
nonspecific esterase is used for identification of certain types, hybrids, classifications, etc. [20]. Analysis of the spectra of acid and alkaline esterase showed that there was not only a difference between $\mathrm{AR}$ and control plants, but also between the number and the location of the isoforms in MS and RF plants. 1- and 2-esterase isozyme distribution revealed differences between the control and experimental groups of sugar beet (Table 3). Experimental MS plants had a new activity zone starting from $R_{f}=$ 0.561 , while there were no such alterations in RF plants.

The isozyme spectrum of cytochrome c oxidase in order to determine some other adaptation features to lower $\mathrm{pH}$ was also studied. The isozyme spectrum analysis of cytochrome $\mathrm{c}$ oxidase demonstrated that there was an extra activity zone starting from $R_{f}=$ 0.631 in experimental MS plants, while in experimental RF plants $R_{f}=0.119$ and $R_{f}=0.663$ zones were absent, and a new activity zone $R_{f}=0.569$ appeared. This enzyme is a part of cell's respiratory metabolism and plays an important role in high-energy compound formation (apart from photosynthesis) by means of mitochondrial respiration. The results presented in this paper demonstrated that $\mathrm{pH}$ stress causes alterations in the isozyme spectrum in AR plants of both MS and RF hybrids.

\section{Conclusions}

It was demonstrated in this study that for cell lines of sugar beet plants, acid medium caused activation or inhibition of synthesis of enzymes in a number of metabolic cycles (the tricarboxylic acid cycle and the pentose-phosphate cycle), as well as the oxidation stress enzymes, such as POD, NADH-DH and cytoplasmic ICL. Adaptation to oxidation stress results in the increase in protein synthesis. While the level of metabolic response of the obtained plants very much depends on the initial genotype of the hybrid. This may be accounted for by the activity of resistance genes. Some of them are expressed from the beginning, while others at the later stages of stress exposure. One of the most obvious symptoms of aluminium toxicity is the slowing down of root growth. It is considered that plants roots produce aluminium ions chelated by organic acids as part of the aluminium tolerance system. The acids are produced during the tricarboxylic acid cycle.

Analysis of biochemical processes in sugar beet regenerants with enhanced acid resistance demonstrated that plant cells are able to regulate the $\mathrm{pH}$ of the cytosol by altering the activity of a number of enzymes.

Due to higher sensitivity of isolated sugar beet tissues to stress factors and dramatic increase in genetic variation, their cultivation allows for higher selection ratio and creation of stable variations on which high-yield next generation hybrids can be based.

\section{References}

[1] Von Uexküll, H. R., and Mutert, E. 1995. "Global Extent, Development and Economic Impact of Acid." Soils Plant Soil 171 (1): 1-15.

[2] Lisitsyn, E. M. 2013. "The Main Reasons of the Low Efficiency of Obtaining Aluminium-Resistant Regenerants of Cereal Crops." Vavilov Journal of Genetics and Selection 17 (1): 89-95.

[3] Sukhoverkova, V. E. 2015. "Changes in Humus Horizon of Black Soils in Case of Long-Term Plowing in Western Siberia." Achievements of Science and Technology of AIC 6: 5-7.

[4] Singh, D., Singh, N. P., Chauhan, S. K., and Singh, P. 2011. "Developing Aluminium-Tolerant Crop Plants Using Biotechnological Tools." Current Science 100 (12): 1807-14.

[5] Pariasca-Tanaka, J., Satoh, K., Rose, T., Mauleon, R., and Wissuwa, M. 2009. "Stress Response Versus Stress Tolerance: A Transcriptome Analysis of Two Rice Lines Contrasting in Tolerance to Phosphorus Deficiency." Rice 2: 167-85.

[6] Pattanayak, A., and Pfukrei, K. 2013. "Aluminium Toxicity Tolerance in Crop Plants: Present Status of Research." African Journal of Biotechnology 12 (24): 3752-7.

[7] Chirkova, T. V. 2002. Physiology of Plants Resistance. Saint Petersburg: Saint Petersburg State University, 244. 

of Sugar Beet (Beta vulgaris L.)

[8] Vanyushin, B. F. 2014. "Epigenetics Today and Tomorrow." Russian Journal of Genetics: Applied Research 4 (3): 168-88.

[9] Artemeva, S. S., Solodilova, O. S., Fedorova, T. S., Homchenkova, G. A., and Eprintsev, A. T. 2002. "The Effect of Salt Stress on the Various Metabolic Pathways Enzymes." In Organization and Regulation of Physiological and Biochemical Processes. Vol. 4. Voronezh, VSU Publishing, 96-102.

[10] Eprintsev, A. T., and Fedorina, O. S. 2006. "Function of Malatdehydrogenase Complex of Maize Mezophyll and Bundle Sheath Cells under Salt Stress Condition." Journal of Stress Physiology and Biochemistry 2 (2): $1-6$.

[11] Gupta, N., Singh, G. S., and Kumar, A. 2013. "Molecular Basis of Aluminium Toxicity in Plants: A Review." American Journal of Plant Science 4: 21-37.

[12] Gladkov, E. A. 2008. "Biotechnological Methods for Obtaining Agrostis stolonifera Plants Resistant to $\mathrm{Cd}$ and Pb." Agricultural Biology 3: 83-7.

[13] Munns, R., and Tester, M. 2008. "Mechanism of Salinity Tolerance." Rev. Plant Biol. 59: 651-81.

[14] Sakano, K. 1998. "Revision of Biochemical pH-Stat: Involvement of Alternative Pathway Metabolism." Plant Cell Physiol. 39 (5): 467-73.

[15] Vitorello, V. A., Capaldi, F. R. C., and Stefanuto, V. A. 2005. "Recent Advances in Aluminum Toxicity and Resistance in Higher Plants." Brazilian Journal of Plant Physiology 17 (1): 129-43.

[16] Cherkasova, N. N., and Zhuzhzhalova, T. P. 2001. "Osmotolerant Plant Sugar Beet Plants Grown in Vitro" Sugar Beet 7: 22-4.

[17] Kosareva, I. A. 2012. "Studying the Resistance Capacity of Agricultural Plants and Their Wild Types to Toxic Elements of Acid Soils." Proc. Russian Acad. Agri. Sci. 170: 35-45.

[18] Znamenskaya, V. V., and Zhuzhzhalova, T. P. 1995. Methodology of Sugar Beet Microcloning. Voronezh: Voronezh State University (VSU), 23.

[19] Zemlyanukhin, A. A., and Zemlyanukhin, L. A. 1996. Study Guide of Plants Physiology and Biochemistry. Voronezh: VSU Publishing, 188.

[20] Levites, E. V. 1986. Genetics of Plants Isoenzymes. Novosibirsk: Nauka Publishing, 145.

[21] Wendel, J. F., and Weeden, N. F. 1989. "Visualization and Interpretation of Plant Isozymes." In Isozymes in Plant Biology, edited by Soltis, D. E., and Soltis., P. S. Portland: Dioscorides Press, 5-45.

[22] Kulaichev, A. P. 2006. "Methods and Tools for Complex Data Analysis." M.: FORUM: INFA, 512.

[23] Polesskaya, O. G. 2007. Plant Cell and Active Reactive Oxygen Intermediates. Moskva: Moscow State
University (MSU).

[24] Rasmusson, A. G., Soole, K. L., and Elthon, T. E. 2004. "Alternative $\mathrm{NAD}(\mathrm{P}) \mathrm{H}$ Dehydrogenases of Plant Mitochondria." Annu. Rev. Plant Biol. 55: 23-39.

[25] Rasmusson, A. G., Geisler, D. A., and Møller, I. M. 2008. "The Multiplicity of Dehydrogenases in the Electron Transport Chain of Plant Mitochondria." Mitochondrion 8 (1): 47-60.

[26] Zemlyanukhina, O. A., Putilina, L. N., Bartenev, I. I., and Zhuzhzhalova, T. P. 2014. "Geographical Zones and Their Effect on Metabolic Characteristics of Sugar Beet PMC-120.” The Federal State Budgetary Scientific Institution "The A.L. Mazlumov All-Russian Research Institute of Sugar Beet and Sugar".

[27] Tyuterev, S. L. 2002. Scientific Basis for Induced Disease Resistance of Plants. Saint Petersburg: RIZO Publishing, 328.

[28] Krüger, N. J., and Von Shaewen, A. 2003. "The Oxidative Pentose Phosphate Pathway: Structure and Organization." Curr. Opin. Plant Biol. 6 (3): 236-46.

[29] Zemlyanukhina, O. A., Cherkasova, N. N., and Zhuzhzhalova, T. P. 2009. "Metabolic Adaptation of in Vitro Sugar Beet Plants to Saline Conditions." In Organization and Regulation of Physiological and Biochemical Processes, Vol. 10, Voronezh: VSU Publishing, 219-25.

[30] Pugin, A., Frachisse, J. M., Tavernier, E., Bligny, R., Gout, E., Douce, R., and Guern, J. 1997. "Early Events Induced by the Elicitor Cryptogein in Tobacco Cells: Involvement of Plasma Membrane NADPH Oxidase and Activation of Glycolysis and the Pentose Phosphate Pathway." Plant Cell 9 (11): 2077-91.

[31] Hauschld, R., and Von Schaewen, A. 2003. "Differential Regulation of Glucose-6-Phosphate Dehydrogenaze Activity in Potato (Solanum tuberosum L.)." Plant Physiol. 133: 47-62.

[32] Zemlyanukhin, A. A., and Zemlyanukhin, L. A. 1995. Metabolism of Plant Organic Acids. Voronezh: VSU Publishing, 152.

[33] Igamberdiev, A. U., and Eprintsev, A. T. 2016. "Organic Acids: The Pools of Fixed Carbon Involved in Redox Regulation and Energy Balance in Higher Plants." Frontiers in Plant Science 7: 1-15.

[34] Zemlyanukhina, O. A., Cherkasova, N. N., and Zhuzhzhalova, T. P. 2009. "Metabolic Adaptation of in Vitro Sugar Beet Plants to Water-Deficiency Conditions." In Organization and Regulation of Physiological and Biochemical Processes, Vol. 11: Voronezh: VSU Publishing, 96-102.

[35] Eprintsev, A. T., Fedorin, D. N., Salnikov, A. V., and Igamberdiev, A. U. 2015. "Expression and Properties of the Glyoxysomal and Cytosolic Forms of Isocitrate 

of Sugar Beet (Beta vulgaris L.)

Lyase in Amaranthus caudatus L.” J. Plant Physiol. 181: 1-8.

[36] Yang, L. T., Qi, Y. P., Jiang, H. X., and Chen, L. S.
2013. "Roles of Organic Acid Anion Secretion in Aluminium Tolerance of Higher Plants." BioMed Research International. doi: 10.1155/2013/173682. 